\title{
Clinical review: The role of biomarkers in the diagnosis and management of community- acquired pneumonia
}

\author{
Mirjam Christ-Crain*1 and Steven M Opal²
}

\begin{abstract}
In patients with community-acquired pneumonia, traditional criteria of infection based on clinical signs and symptoms, clinical scoring systems, and general inflammatory indicators (for example, leukocytosis, fever, C-reactive protein and blood cultures) are often of limited clinical value and remain an unreliable guide to etiology, optimal therapy and prognosis. Procalcitonin is superior to other commonly used markers in its specificity for bacterial infection (allowing alternative diagnoses to be excluded), as an indicator of disease severity and risk of death, and mainly as a guide to the necessity for antibiotic therapy. It can therefore be viewed as a diagnostic, prognostic, and perhaps even theragnostic test. It more closely matches the criteria for usefulness than other candidate biomarkers such as C-reactive protein, which is rather a nonspecific marker of acute phase inflammation, and proinflammatory cytokines such as plasma IL-6 levels that are highly variable, cumbersome to measure, and lack specificity for systemic infection. Elevated levels of pro-adrenomedullin, copeptin (which is produced in equimolar amounts to vasopressin), natriuretic peptides and cortisol are significantly related to mortality in community-acquired pneumonia, as are other prohormones such as pro-atrial natriuretic peptide, coagulation markers, and other combinations of inflammatory cytokine profiles. However, all biomarkers have weaknesses as well as strengths. None should be used on its own; and none is anything more than an aid in the exercise of clinical judgment based upon a synthesis of available clinical, physiologic and laboratory features in each patient.
\end{abstract}

*Correspondence: mirjam.christ-crain@unibas.ch

'Division of Endocrinology, Diabetes and Clinical Nutrition, University Hospital Basel, Petersgraben 4, CH-4031 Basel, Switzerland

Full list of author information is available at the end of the article

\section{Introduction}

Numerous non-infectious processes can produce respiratory symptoms and new pulmonary infiltrates with systemic inflammatory signs and symptoms with fever, leukocytosis and acute phase reactants that can be easily confused with bacterial pneumonia. Typically, Gram stains of respiratory secretions are often unavailable or are difficult to evaluate, and microbiological culture reports take 24 to 48 hours. A negative sputum culture in a patient suspected of having community-acquired pneumonia (CAP) does not rule out the possibility of severe bacterial infection.

The standard methods used today to diagnose CAP have not changed appreciably since Pasteur and Sternberg first cultured pneumococci from sputum in 1881 and Christian Gram first applied his now famous stain to examine sputum specimens 5 years later. Acquiring highquality sputum samples for culture and interpreting these culture results remain elusive clinical challenges. There are no unequivocal clinical predictors of disease severity, although many clinical scoring systems currently exist for this purpose. No generally agreed criteria exist for determining which patients should be admitted to the hospital medical service or to the intensive care unit (ICU). Given these areas of uncertainty in clinical decision-making, a concerted effort has been undertaken to develop reliable and practical biomarkers for the diagnosis, risk prediction and management of CAP.

To be helpful in routine clinical practice, a biomarker should provide additional actionable information - not already available by standard methods - that accomplishes at least one or more of the following: assists in establishing a rapid and reliable diagnosis; provides an indication of prognosis; selects those patients most likely to benefit from a specific intervention; reflects the efficacy or lack of efficacy of specific interventions; warns in advance of disease progression; exhibits a large amplitude of variation; and does not show an exhaustion or fatigue phenomenon, meaning that during prolonged and successive infections its levels remain elevated and always responsive to the infectious stimulus [1]. 
Table 1. Table of biomarkers

\begin{tabular}{|c|c|c|}
\hline & Widely available biomarkers & Potential future biomarkers \\
\hline \multirow[t]{3}{*}{ Biomarkers of inflammation } & Tumor necrosis factor alpha & $\mathrm{IL}-1 \beta$ \\
\hline & Lactate & $\mathrm{IL}-6$ \\
\hline & & $\mathrm{IL}-10$ \\
\hline \multirow[t]{5}{*}{ Biomarkers of coagulation } & Activated partial thromboplastin time & Protein C \\
\hline & Platelets & D-dimer \\
\hline & Fibrinogen & Thrombin-antithrombin complexes \\
\hline & Disseminated intravascular coagulation scores & Prothrombin fragment 1.2 \\
\hline & & Activated partial thromboplastin time waveform analysis \\
\hline \multirow[t]{6}{*}{ Biomarkers of infection } & C-reactive protein & Adrenomedullin \\
\hline & Procalcitonin & Pro-adrenomedullin \\
\hline & Blood urea nitrogen & B-type natriuretic peptide \\
\hline & Leukocytes & $\begin{array}{l}\text { Triggering receptor expressed on myeloid cells-1 (soluble } \\
\text { triggering receptor expressed on myeloid cells-1) }\end{array}$ \\
\hline & Endotoxin & High mobility group box-1 \\
\hline & PCR & \\
\hline Biomarkers of stress & Cortisol & Copeptin \\
\hline
\end{tabular}

Within the context of clinical trials, a biomarker might also prove useful in identifying patients suitable for enrollment into a clinical study. Biomarkers might define the nature of their disease or its severity, provide insights into the drug's mechanism of action, establish which groups of patients within a trial population experience the greatest benefit, or serve as a surrogate for long-term outcome such as mortality. To be of greatest practical value, a candidate assay for a biomarker needs to provide quantitative information that is both reliable and reproducible. Moreover, the ideal biomarker measurement should be rapid, easy and inexpensive to perform.

The present brief review examines the currently available biomarkers, and those under development, and asks whether they add sufficiently valuable, explanatory information over traditional diagnostic and prognostic criteria for CAP to warrant their routine use and improve patient management. We summarize the existing evidence about the utility of markers that are already available clinically. A substantial number of biomarker assays are in the development process, and some of these assays are likely to assume an increasingly important role in clinical management of CAP in the future.

\section{Search strategy}

A Medline and PubMed search of relevant medical literature in the English language published in the past 15 years was performed using search terms including community-acquired pneumonia, clinical scoring systems for pneumonia, biomarkers for infection and inflammation, prognostic factors, pneumonia severity indicators, and surrogate markers of pneumonia severity. The papers chosen for study were reviewed by one or both of the authors for evidence and consistency of the data. Older literature and existing meta-analyses or other systematic reviews of the topic were included when they added additional significant insights and evidence.

Table 1 summarizes the discusses biomarkers.

\section{Markers that may aid diagnosis}

\section{Procalcitonin, C-reactive protein and leukocyte count}

The diagnostic and prognostic accuracy of clinical signs and symptoms and a range of laboratory markers were recently assessed in a planned post hoc analysis of 545 patients with suspected lower respiratory tract infection admitted to the emergency department [2]. In a receiver operating characteristic analysis to determine the diagnostic accuracy for CAP, the area under the curve of a clinical model including fever, cough, sputum production, abnormal chest auscultation and dyspnea was 0.79 . Including values for procalcitonin (PCT) and highly sensitive $\mathrm{C}$-reactive protein (CRP) increased the area under the curve to 0.92 , which was significantly better than the areas under the curve for PCT, CRP and clinical signs and symptoms alone (Figure 1). The contribution to diagnostic reliability made by PCT was substantially greater than that made by CRP, which in turn performed better than the total leukocyte count. Clinical criteria such as sputum production and physical examination with chest auscultation were surprisingly poor predictors for the diagnosis of CAP. The added value of the PCT biomarker as a clinical decision-making tool is evidenced in the present study and many other studies involving PCT measurement [3-9]. 


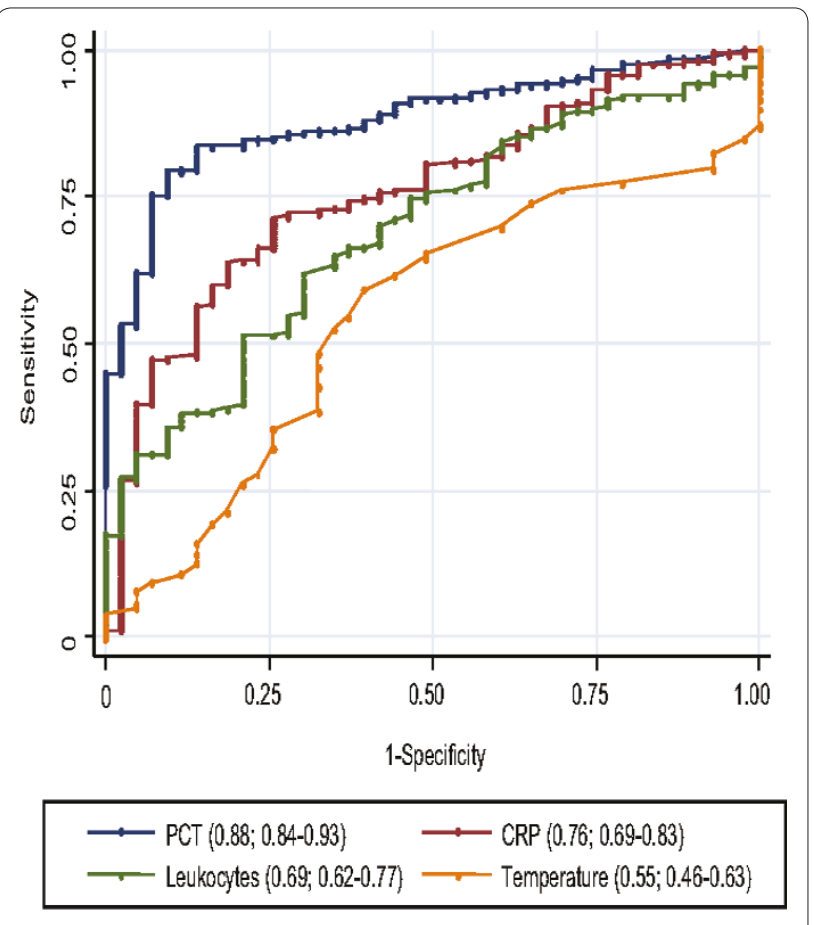

Figure 1. Diagnostic accuracy of different biomarkers for community-acquired pneumonia. Receiver operating characteristics (ROC) curves for diagnostic accuracy to predict radiographically suspected community-acquired pneumonia (CAP) including other non-infectious diagnoses initially diagnosed as CAP plus patients without a clinically relevant bacterial etiology of CAP. Values show areas under the ROC curve with $95 \%$ confidence intervals. CRP, C-reactive protein; PCT, procalcitonin.

PCT is a pre-pro-peptide precursor of the thyroid hormone calcitonin [10]. Mature calcitonin is named after its mild and transient hypocalcemic effect and was originally thought to play an important role in calcium homeostasis. Thyroidectomy in humans has no important pathologic consequences, however, provided thyroid hormone is replaced: calcium homeostasis remains intact, suggesting that the function of the mature calcitonin in humans is no longer essential [11].

Circulating levels of the precursor hormone PCT, derived primarily from nonthyroidal tissues, can rise several thousand times above normal in various inflammatory conditions, but most notably in bacterial infection [4]. In differentiating bacterial infection from noninfective causes of inflammation in hospitalized patients, a meta-analysis concluded that PCT was both more sensitive $(85 \%$ vs. $78 \%)$ and more specific $(83 \%$ vs. $60 \%)$ compared with CRP. PCT was also more sensitive in differentiating between a bacterial etiology and a viral etiology [7].

Use of PCT as a biomarker is increasingly common in Europe, not only in the diagnosis of sepsis but also in less severe infections such as CAP. The value of PCT depends on the clinical setting in which it is used and, crucially, on the sensitivity of the assay. The Kryptor assay (Brahms, Hennigsdorf, Germany) has a functional sensitivity of $0.06 \mu \mathrm{g} / \mathrm{l}$ (between threefold and 10-fold above the normal mean value). This assay reliably detects even mild/ moderately elevated PCT $[12,13]$. In routine practice, results are available within 1 hour. Such assay devices are now widely available in many larger hospitals and clinical laboratories. A rapid bedside test that can also be used in smaller laboratories and in general practice is currently in development. The Food and Drug Administration has approved the more sensitive assay in the USA; however, approval has only been given for the indication of progression from severe sepsis to septic shock.

One particularly important role of PCT measurement appears to be in allowing certain diagnoses to be excluded. A PCT value below a specific threshold level (according to most studies, $0.25 \mu \mathrm{g} / \mathrm{l}$ ) makes it very unlikely a patient has severe CAP [7]. It should be noted that PCT levels may be high when measured in patients with non-infectious, systemic inflammatory states such as severe trauma, recent surgery, or burns [14]. In the absence of infection, however, PCT levels generally decline to below $1 \mathrm{ng} / \mathrm{ml}$ (or $1 \mu \mathrm{g} / \mathrm{l}$ ) within 48 hours, pointing to the importance of repeated measurements of PCT with high-sensitivity assays [15]. Furthermore, it must be acknowledged that the extent of the inflammatory response attributable to infection (that is, the signal) is often limited - due to the relatively low virulence of many of the causative microorganisms found in ventilator-associated pneumonia, as compared with the omnipresent underlying systemic inflammatory response syndrome already existing in every intubated, critically ill patient (that is, the noise). The resulting lower signalto-noise ratio in ventilator-associated pneumonia limits the diagnostic accuracy of biomarkers such as PCT in ventilator-associated pneumonia. Serial measurements of PCT over time are informative, and trend lines of absolute values are more useful than the percentage decrease from baseline values.

In contrast to PCT, the routine laboratory tests for CRP and the white cell count lack specificity for bacterial infection; a high CRP could be due to numerous other inflammatory conditions or ischemic injury including myocardial infarction. Administration of steroids does not diminish the value of PCT [16]. For CRP, recent data suggest that steroids do not influence CRP levels in patients with CAP [17].

A wealth of publications in the medical literature over the past 10 years support the diagnostic utility of PCT for acute systemic bacterial infections [18-22]; yet in a recent meta-analysis, Tang and colleagues questioned the validity of PCT in differentiating sepsis from non-infectious causes of systemic inflammatory response syndrome [23]. The differences between this study and the meta-analysis 
of Simon and colleagues can mainly be explained by different inclusion criteria [7]. As pointed out in a response to this meta-analysis from Reinhart and Brunkhorst [24], the search strategy and strict inclusion criteria used in the meta-analysis can be questioned, and it is debatable whether exclusion of abdominal sepsis patient and septic shock patient populations is appropriate.

Other studies found a good diagnostic performance for CRP $[25,26]$ and found better diagnostic accuracy for CRP as compared with PCT [27]. Importantly, however, it must be pointed out that all observational studies and metaanalyses are susceptible to potential publication selection bias. Only randomized controlled intervention studies have the potential to resolve the controversial topic (see section As a guide to therapy). Intervention studies in patients with pneumonia are only available for PCT, but not for CRP. Future intervention studies should focus on a direct head-to-head comparison of these two biomarkers.

\section{Proinflammatory cytokines}

The presence in the bloodstream of lipopolysaccharide, sometimes referred to as endotoxin, is taken by the host as evidence of invasion by pathogenic Gram-negative bacteria [28]. In point of fact, endotoxemia is quite prevalent even in Gram-positive sepsis or fungal sepsis. The explanation for this finding is related to shock-induced gut ischemia with splanchnic hypoperfusion and increased intestinal permeability. Impaired mucosal barrier function is accompanied by egress of lipopolysaccharide found in the lumen of the gut from endogenous enteric Gram-negative bacteria into the systemic circulation [29]. The host responds by releasing an array of inflammatory mediators and procoagulant factors.

In principle, these factors, or the measurement of lipopolysaccharide itself, could constitute markers indicative of severity of disease [28]. While cytokine expression and release in the circulation are common events in systemic inflammatory states, however, the standard proinflammatory cytokines such as TNF $\alpha$, IL-1 $\beta$ and IL- 6 have proven to be unreliable indicators of specific infections such as severe CAP for a number of reasons. These cytokines have short serum half-lives and the blood levels are highly variable, transient, and nonspecific. IL-1 and TNF are present in very low concentrations (picomolar levels) in most infectious disease states and are therefore difficult to measure [30].

Of the myriad of cytokines and chemokines that can be measured in the circulation during acute inflammation, IL- 6 may be the best studied and most valuable as a prognostic indicator [31]. Multiplex assays now permit simultaneous measurement of multiple cytokines with relative ease [32]. A paper by Kellum and colleagues using a large database from the GenIMS study of CAP demonstrated a clear correlation between the ratio of IL-6 to IL-10, and the risk of mortality in patients with CAP [33]. Patients with elevated levels of both IL-6 and IL-10 had a risk of death more than 20 times higher than patients with low levels of both cytokines $(P<0.001)$.

In a prospective cohort study investigating all-cause and cause-specific 1-year mortality in CAP survivors [34], higher IL-6 and IL-10 concentrations at hospital discharge were associated with an increased risk of death, which gradually fell over time. For each log-unit increase, the range of adjusted hazard ratios for IL- 6 was 1.02 to $1.46(P<0.0001)$, and the range for IL-10 was 1.17 to 1.44 $(P=0.01)$. High IL-6 concentrations were particularly associated with death due to cardiovascular disease, cancer, infections, and renal failure $(P=0.008)$. These investigations pointed out that cytokine levels might actually be more predictive of adverse outcome when measured at the end of hospitalization rather than the traditional measurement of cytokines in the early phases of seeking medical attention. The same has been shown for CRP [35].

\section{Triggering receptor expressed on myeloid cells-1, high mobility group box- 1 and other potential markers}

Triggering receptor expressed on myeloid cells- 1 is upregulated by microbial products [36]. Soluble triggering receptor expressed on myeloid cells- 1 in bronchoalveolar lavage fluid accurately identifies bacterial or fungal pneumonia in mechanically ventilated patients, and is superior in this regard to clinical findings or other laboratory values. Such lavage is not appropriate, however, in the routine care of patients with severe CAP. In this severe CAP setting, measurement of soluble triggering receptor expressed on myeloid cells-1 in plasma or serum has proved unhelpful as a guide to either etiology or outcome [37].

High mobility group box-1 nonhistone nucleoprotein is released from damaged cells and during systemic inflammation, and has proven to be a promising, late marker of disease severity. Circulating blood levels of high mobility group box-1 are high and remain high in patients with severe sepsis [38]. In a study in CAP patients, high mobility group box-1 levels were frequently measurable, even at the time of hospital discharge, and were not helpful as a long-term prognostic indicator [39]. Further study of this remarkable plasma protein is warranted in the future to determine its practical clinical value in the management of severe CAP.

Other biomarkers are continuously being discovered in animal and human experimental pneumonia models, as well as in ongoing clinical investigations. Many of these markers will undoubtedly be proposed for the diagnosis and management of CAP in the future.

\section{Early microbial diagnosis and susceptibility testing}

Molecular biomarkers for rapid microbial diagnosis using real-time PCR and similar nucleic acid-based, nonculture 
methods are now available in some centers and will soon become routinely available in the clinic [40,41]. Such techniques should facilitate early detection of bacteremia, should speed precise diagnosis of microbial pathogens, and should allow rapid initiation of appropriately targeted antibiotic therapy.

A recent study demonstrated that the availability of real-time PCR could distinguish Staphylococcus aureus from coagulase-negative staphylococci and could detect methicillin resistance in 90 minutes [42]. This molecular technique permits early diagnosis and appropriate therapy, and use of the procedure will probably become the standard of care in the next few years.

\section{Indicators of prognosis}

CAP is the leading cause of death from infection in western countries [43]. Ideally, the management strategy and nature of the intervention for CAP (including the need for hospitalization and admission to intensive care) would be tailored to the severity of disease and mortality risk in the individual patient. In the emerging era of personalized medicine, with rapid diagnosis and therapeutic strategies based upon unique patient characteristics, focused care will be directed by advanced systems biology to minimize potential harm and to maximize the efficacy of each intervention [44]. These great expectations are predicated upon the widely held belief that rapid access to improved biomarkers will permit this type of high-level individualized care. Such biomarkers will need to demonstrate superiority over standard clinical criteria alone (that is, clinical scoring systems) in adequately powered prospective studies. Examples of the clinical value of such scoring systems will be discussed in the following paragraphs.

\section{Comparisons between biomarkers and global severity scoring systems for community-acquired pneumonia}

Biomarkers for CAP are often compared with global measures of disease severity using clinical scoring systems. Developed by analyzing data from over 14,000 cases of CAP, the pneumonia severity index (PSI) uses a twostep algorithm to divide patients into five classes based on the risk of death within 30 days [45]. The index, which integrates data about age and coexisting disease with values on a range of clinical and laboratory findings, was validated among more than 40,000 cases in the Pneumonia Patient Outcomes Research Team cohort. The PSI potentially overemphasizes the importance of age, however, and inter-observer variability may lead to misclassification of patients, especially at the more severe end of the spectrum. The PSI has the disadvantage of dichotomizing continuous variables into normal/abnormal (to make it more user-friendly), and yet it is still complex enough to discourage routine adoption.
The CURB-65 score is a simpler severity score developed by the British Thoracic Society, based on only five factors (confusion, urea nitrogen, respiratory rate, blood pressure, and age 65 and older). It is an easily measured alternative to the PSI and is widely used in Europe [46].

Logistical regression analysis of data from the Australian CAP study has led to the development of the SMARTCOP method of scoring severe pneumonia [47]. The features statistically significantly associated with receipt of invasive respiratory or vasopressor support were low systolic blood pressure, multilobar chest radiography involvement, low albumin level, high respiratory rate, tachycardia, confusion, poor oxygenation, and low arterial $\mathrm{pH}$ : SMART-COP. A SMART-COP score $\geq 3$ points identified $92 \%$ of patients who received invasive respiratory or vasopressor support, including $84 \%$ of patients who did not need immediate admission to the ICU.

Finally, the updated prediction model from the 2007 Infectious Disease Society of America-American Thoracic Society guidelines for management of CAP [48] is also widely used. This scores pneumonia severity based on the presence of two major criteria (need for mechanical ventilation or therapeutic vasopressors) or several minor criteria. The presence of at least one of these major criteria or at least three of the minor criteria should prompt admission to the ICU.

\section{Procalcitonin, other hormokines and cortisol as prognostic indicators in community-acquired pneumonia}

During inflammation and infection, certain hormones behave like cytokines: hence the term hormokines, of which PCT is the prototype. Others that have attracted attention as potentially useful prognostic markers include adrenomedullin (ADM), the natriuretic peptides (atrial natriuretic peptide and B-type natriuretic peptide) and copeptin, which mirrors vasopressin. Assays for proADM, pro-atrial natriuretic peptide and $\mathrm{B}$-type natriuretic peptide have recently become commercially available in Europe. Clinical experience with these peptide precursor molecules are limited to date but so far compare favorably with PCT [49-51]. Consideration of the potential value of measuring these peptides, along with that of an assay for cortisol, which has long been readily available, is therefore timely.

PCT is a more powerful guide to prognosis in pneumonia than several more commonly used biomarkers. In the post hoc analysis of data from 545 patients described above [2], raised PCT was significantly related to increasing severity of CAP as assessed by the PSI. CRP and the leukocyte count did not show the same systematic relationship. The prognostic value of PCT can be markedly increased by serial measurement. The relative risk of mortality in the ICU was thus 1.8 for critically ill patients, showing PCT increases over 1 day - increasing to 2.8 among patients whose PCT rose over 3 days [52]. 
Increasing CRP levels or white cell count did not predict mortality. In contrast, in a recent paper, CRP measured on admission and on day 3 after admission predicted treatment failure and differentiated early from late treatment failure [53]. Persistently high levels of PCT are associated with worse outcome [54]. In contrast, a falling level of PCT, which often follows a log-linear curve with a halflife of 20 to 24 hours, suggests a favorable outcome. Luyt and colleagues demonstrated that the kinetics of PCT also have prognostic implications in patients with ventilatorassociated pneumonia [55].

In patients with CAP, total serum cortisol levels increase with increasing severity of disease as assessed by the PSI [56]. This relationship was not evident with CRP or the leukocyte count. Cortisol levels in survivors were significantly lower at baseline than those in nonsurvivors. In a receiver operating characteristic analysis to predict survival, the area under the curve for cortisol was 0.76 , the same value as that for the PSI. PCT, CRP and the leukocyte count were all less predictive. In this study, measurement of free cortisol had no advantage over measurement of serum total cortisol [56]. One notable limitation of cortisol, however, is that it cannot be used in patients receiving steroids.

Like cortisol, copeptin mirrors the individual stress level - and it is most probably this reflection of the stress level that enables them both to predict outcome. Copeptin reflects individual stress at a higher (that is, hypothalamic-pituitary) level, whereas cortisol levels mirror the more peripheral stress response of the adrenals [57]. In a cohort of 373 patients with CAP, copeptin increased with increasing severity of the PSI and was an independent predictor of outcome, in contrast to other clinical symptoms and findings [49].

In a study of 302 patients admitted to the emergency department with CAP, a range of potential biomarkers was studied [58]. Levels of proADM (a member of the calcitonin gene family extensively expressed during infection) increased with increasing disease severity, as reflected in the PSI score. Among patients who died during follow-up, proADM levels on admission were significantly higher than in survivors. ProADM was more closely related to mortality than PCT, CRP or the leukocyte count, and had approximately the same prognostic accuracy as the PSI. The correlation between proADM and the PSI was only around $50 \%$, indicating that proADM provides information not captured in the PSI. Taking proADM into account in assessing mortality risk significantly increased the predictive value of a model based on the PSI alone. Importantly, patients with a high proADM level were at high risk of mortality even when they were low risk according to the PSI.

\section{Markers of coagulation}

Activation of coagulation and concomitant downregulation of anticoagulant systems and impaired fibrinolysis are prominent features of severe sepsis. There is an important interaction - mediated at least in part by protease-activated receptors - between inflammatory mechanisms and coagulopathy [59]; both systems are consistently activated by severe infection and inflammatory states.

Among the markers that have been suggested as predictors of adverse outcome are prothrombin fragments (PF1.2), thrombin-antithrombin complexes (TATc) caused by the complexing of thrombin with its naturally occurring inhibitor, and D-dimer, a degradation product of cross-linked fibrin indicative not just of coagulation but also of fibrinolysis.

In CAP, baseline D-dimer shows a strong relationship with mortality in patients with a PSI of 5 [60]. The International Society of Thrombosis and Hemostasis disseminated intravascular coagulation (DIC) score [61] and similar DIC scoring systems - for example, the modified Japanese Association for Acute Medicine DIC score [62] - are also highly predictive of outcome in severe sepsis patients; the majority of these patients had severe pneumonia as the cause of severe sepsis [63]. Additionally, patients with a genetic predisposition to impaired fibrinolysis (elevated plasminogen activator inhibitor-1 levels) have a greater propensity to develop pneumonia [64].

\section{Waveform analysis of activated partial thromboplastin time} The presence of an abnormal biphasic transmittance waveform during measurement of the activated partial thromboplastin time (aPTT) has been found more accurate than either PCT or CRP in distinguishing those patients with severe sepsis or septic shock among a wider population meeting at least two criteria of systemic inflammatory response syndrome [65]. The biphasic waveform of clot generation is related to a complex of CRP and lipoproteins that alters the rate of change in plasma transmittance as clotting occurs. This biphasic wave form is captured on specific optics systems on some aPTT machines. The biphasic waveform measure can also provide prognostic information: values on days 1 to 3 following admission were significantly more abnormal in sepsis patients who subsequently died than in sepsis patients who survived or in nonsepsis patients who died. An aPTT waveform analysis can be easily and quickly undertaken, and - although this study was conducted in a surgical ICU [65] - its findings may have implications for the diagnosis of infection in patients with severe CAP.

A further study, conducted in 200 patients on a medicosurgical ICU, demonstrated that combining aPTT waveform analysis with PCT increased its specificity in the identification of sepsis in acutely ill patients [66]. Of 60 patients with an abnormal PCT $(>1 \mathrm{ng} / \mathrm{ml})$ at admission, $40 \%$ were subsequently diagnosed with sepsis. Among the 30 patients who had both an abnormal PCT and an 
abnormal aPTT waveform, $77 \%$ had sepsis. It should be noted that the use of aPTT waveform studies as a diagnostic platform thus far have not specifically focused upon CAP patients. These reports measure the diagnostic utility of biphasic wave form analysis for sepsis from many sources and tissue sites of severe infection.

\section{Disseminated intravascular coagulation scores}

A substantial literature links global assessment of coagulation dysfunction, based on widely available laboratory tests, to poor prognosis. Retrospective analysis of data from the placebo group in the PROWESS trial of drotrecogin alfa show a significant relationship between an increasing International Society of Thrombosis and Haemostasis DIC score (based on the prothrombin time, D-dimer level, fibrinogen and platelet count) and 28-day mortality [63]. This relationship was independent of, and stronger than, that of age or the Acute Physiology and Chronic Health Evaluation II score.

In one prospective study, each point increment in the International Society of Thrombosis and Hemostasis DIC score increased the odds ratio for 28-day mortality by 1.25. The pattern of coagulation activation may be more helpful than any individual parameter. Interestingly, an abnormal aPTT waveform correlated highly with the DIC score, and in $19 \%$ of patients was evident before diagnosis could be made on the basis of the scoring system [61]. Patients with severe CAP show abnormalities of coagulation [67], and an absence of these markers is useful in ruling out clinical sepsis.

\section{As a guide to therapy}

Despite the fact that the majority of lower respiratory tract infections are viral in origin, antibiotics are frequently prescribed, especially in patients who are critically ill (for example, the highest misuse of antibiotics in respiratory tract infections is seen in general practice) [68]. In the Pro-Resp trial evaluating PCT in the emergency department, patients with lower respiratory tract infections were randomized to traditional antibiotic management or to management guided by PCT [13]. Use of antibiotics was discouraged when the PCT level was $<0.1 \mu \mathrm{g} / \mathrm{l}$ or $<0.25 \mu \mathrm{g} / \mathrm{l}$. In patients randomized to management using the PCT algorithm, antibiotic usage was one-half that in the traditionally managed group, without clinical or laboratory outcome being compromised.

Although CAP is more likely to be bacterial, such organisms are typically identified in fewer than $50 \%$ of cases. Delayed use of antibiotics, however, is associated with increased mortality [69]. In a randomized trial in this setting, PCT-guided therapy reduced the duration of antibiotic therapy from a median of 12 days to 5 days without compromising the overall $83 \%$ success rate of treatment [70] (Figure 2).
In the setting of general practice, $\mathrm{PCT}$ has been shown to reduce antibiotic exposure by $72 \%$ [71]. In a recent study, CRP also showed potential to reduce antibiotic prescription, but to a smaller extent [72].

\section{Genetic and proteomic markers}

There are genetic factors associated with increased risk of contracting severe CAP. A large number of SNPs and haplotypes are associated with worse outcome and are therefore prognostic. Genomics therefore has potential as a source of markers relevant to the disease.

Clinically, systemic inflammatory response syndrome of different etiologies present in a similar way. Gene expression profiles in patients with systemic inflammatory response syndrome arising from infection and subsequently leading to sepsis have been compared with those in patients whose systemic inflammatory response syndrome was due to other causes [73]. On the Affymetrix microarray, upregulation or downregulation of several hundred genes distinguished between patients whose inflammatory condition was caused by infection and those whose respiratory syndrome was non-infective in origin. The genes that differentiated between etiologies involved four areas: innate immunity, cytokine receptors, T-cell differentiation, and regulation of protein synthesis.

Despite evidence of differential gene expression in Gramnegative and Gram-positive sepsis in a murine model [74], gene expression profiles in critically ill patients with Grampositive and Gram-negative sepsis do not differ [75].

Genetic factors related to cytokine expression may also influence outcomes. Patients with pulmonary sepsis who were found to have a specific CGG haplotype associated with low IL-10 production demonstrated significantly higher mortality than patients who had alternative haplotypes [76]. This higher mortality was not seen with other sources of infection. Polymorphisms in the human genome within the genes that regulate early signal transduction events of the innate immune response, including Mal [77], IRAK-4 [78], and MyD88 [79], all increase the risk of invasive bacterial pneumonia. Mutations and polymorphisms in the human genome to complement systems [80], to mannose-binding lectin systems [81], and to the coagulation and fibrinolytic systems $[82,83]$ also alter the risk and prognosis of invasive bacterial pneumonia. Undoubtedly, more genomic evidence of disease risk, treatment response, and prognosis in CAP will become available as functional genomics and transcriptomics becomes the standard of care in critical care units in the near future.

The technology of proteomic profiling is becoming cheaper and is reaching the stage of clinical feasibility for large interventional trials. At present, however, little information is available about proteomics in clinical trials in CAP. Several such studies are ongoing and the results will be of considerable interest. 


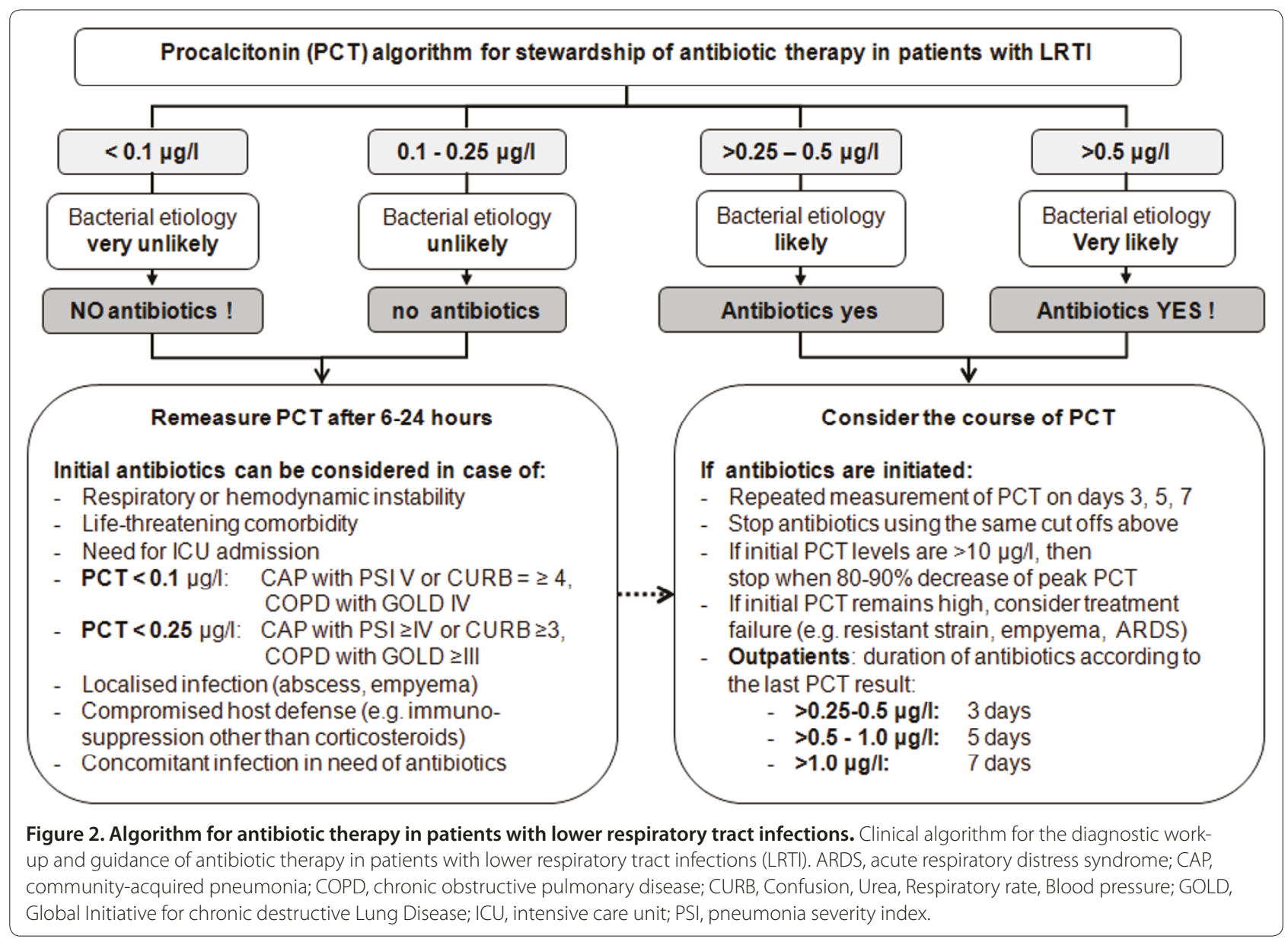

\section{Discussion and conclusion}

In clinical infection, there is a highly variable interaction between microbes, their toxins, and the host response. The complexity that emerges cannot be represented by a single biomarker, let alone a single measurement of a biomarker. For example, one PCT value - however low should not be grounds for ruling out antibiotic therapy in an adult patient with suspected CAP. PCT is not a marker of very early infection - that is, it increases about 6 hours after a stimulus [22] - underlying the importance of remeasurement. A single value on admission (in contrast to serial measurement showing changes in PCT with time) is not a good indicator of prognosis. A high PCT and an increase for 1 day is an early indicator for mortality in ICU patients [52]. The information that such markers provide must be interpreted with caution and in context. Markers should be considered only in conjunction with clinical history and examination, and in the light of experience. Furthermore, a complete knowledge of the biology, strengths, and limitations of the marker is important before using it as a routine clinical tool.

It is also important to note that markers may be influenced by therapy. Immunoactive agents such as steroids are frequently used in acutely ill patients and are not necessarily taken adequately into account when measuring biomarkers. Administration of steroids is known to affect levels of cortisol, for example. This steroid effect may be true of other markers, including natriuretic peptides, although the evidence for this presently comes from an endotoxemia model in healthy subjects rather than from patients with CAP [16]. PCT, however, seems not to be affected by steroids. A Japanese study shows that PCT has good specificity in distinguishing acute bacterial infections from disease flare in patients with autoimmune diseases even when they are taking steroids [84]. The same seems to be true for CRP [17]. Markers may also be influenced by renal function. Uremia in patients with endstage renal disease seems to increase PCT levels, and the PCT levels declined after each hemodialysis session [85]. Accordingly, cutoff levels to diagnose bacterial infection may have to be adapted in patients with renal dysfunction [86].

The future may lie in combining information from several markers, each reflecting a different aspect of disease. Such a panel might include one marker of bacterial infection, one marker reflecting disordered coagulation, one 
hormone, and one proinflammatory cytokine. This proposal draws plausibility from evidence for the incremental value of combining markers of left ventricular dysfunction, myocardial cell damage, renal failure and inflammation in predicting cardiovascular deaths among older men $[81,87]$. Incorporating the four biomarkers significantly improved the prognostic value of a model based only on established risk factors such as age, blood pressure and hyperlipidemia. Interestingly, two of the four markers involved in predicting cardiovascular risk (pro-brain natriuretic peptide and CRP) overlap with those discussed above in the context of severe CAP.

It is also relevant to note that a marker valid for one purpose - such as diagnosis - may not be the most helpful in establishing a prognosis or in aiding particular therapeutic decisions. PCT, for example, has proven value in ruling out nonbacterial causes of inflammation and in guiding antibiotic use; however, a single measurement of PCT on admission is possibly not as predictive of mortality risk as a single measurement of proADM or cortisol in patients without steroid pretreatment.

\section{Abbreviations}

$\mathrm{ADM}=$ adrenomedullin; aPPT = activated partial thromboplastin time; $\mathrm{CAP}=$ community-acquired pneumonia; CRP = C-reactive protein; DIC $=$ disseminated intravascular coagulation; $I C U=$ intensive care unit; $I L=$ interleukin; $\mathrm{PCR}=$ polymerase chain reaction; $\mathrm{PCT}=$ procalcitonin; $\mathrm{PSI}=$ pneumonia severity index; SNP = single nucleotide polymorphism; TNF = tumor necrosis factor.

\section{Acknowledgements}

The authors would like to acknowledge the assistance of Rob Stepney and Brian McMunn with manuscript preparation. The authors retained full control over content identification and selection, and final approval of the manuscript.

\section{Author details}

'Division of Endocrinology, Diabetes and Clinical Nutrition, University Hospital Basel, Petersgraben 4, CH-4031 Basel, Switzerland

Warren Alpert Medical School of Brown University, Infectious Disease Division, Memorial Hospital of Rhode Island, 111 Brewster Street, Pawtucket, RI 02860, USA

\section{Competing interests}

MC-C received consulting fees and speaking honoraria from BRAHMS AG and Biomerieux AG, the manufacturer of the PCT assay. SMO was a lead investigator in the TFPI CAPTIVATE study and a co-worker in the Ocean State clinical coordinating center that received a grant from Novartis to assist in the conduct of this trial, and receives research grants from Eisai, Inimex, and Atox bio.

\section{Published: 8 February 2010}

\section{References}

1. Povoa P: Serum markers in community-acquired pneumonia and ventilator-associated pneumonia. Curr Opin Infect Dis 2008, 21:157-162.

2. Muller B, Harbarth S, Stolz D, Bingisser R, Mueller C, Leuppi J, Nusbaumer C, Tamm M, Christ-Crain M: Diagnostic and prognostic accuracy of clinical and laboratory parameters in community-acquired pneumonia. BMC Infect Dis 2007, 7:10.

3. Becker KL, Nylen ES, White JC, Muller B, Snider RH, Jr: Clinical review 167: procalcitonin and the calcitonin gene family of peptides in inflammation, infection, and sepsis: a journey from calcitonin back to its precursors. J Clin Endocrinol Metab 2004, 89:1512-1525.

4. Joyce CD, Fiscus RR, Wang X, Dries DJ, Morris RC, Prinz RA: Calcitonin generelated peptide levels are elevated in patients with sepsis. Surgery 1990, 108:1097-1101.
5. Muller B, Becker KL, Schachinger H, Rickenbacher PR, Huber PR, Zimmerli W, Ritz R: Calcitonin precursors are reliable markers of sepsis in a medical intensive care unit. Crit Care Med 2000, 28:977-983.

6. Weglohner W, Struck J, Fischer-Schulz C, Morgenthaler NG, Otto A, Bohuon C, Bergmann A: Isolation and characterization of serum procalcitonin from patients with sepsis. Peptides 2001, 22:2099-2103.

7. Simon L, Gauvin F, Amre DK, Saint-Louis P, Lacroix J: Serum procalcitonin and C-reactive protein levels as markers of bacterial infection: a systematic review and meta-analysis. Clin Infect Dis 2004, 39:206-217; erratum 2005, 40:1386.

8. Assicot M, Gendrel D, Carsin H, Raymond J, Guilbaud J, Bohuon C: High serum procalcitonin concentrations in patients with sepsis and infection. Lancet 1993, 341:515-518.

9. Uzzan B, Cohen R, Nicolas P, Cucherat M, Perret GY: Procalcitonin as a diagnostic test for sepsis in critically ill adults and after surgery or trauma: a systematic review and meta-analysis. Crit Care Med 2006, 34:1996-2003.

10. Le Moullec JM, Jullienne A, Chenais J, Lasmoles F, Guliana JM, Milhaud G, Moukhtar MS: The complete sequence of human preprocalcitonin. FEBS Lett 1984, 167:93-97.

11. Silva O, Wisneski LA, Cyrus J, Snider RH, Moore CF, Becker KL: Calcitonin in thyroidectomized patients. Am J Med Sci 1978, 275:159-164.

12. Snider $\mathrm{RH}$, Jr, Nylen ES, Becker KL: Procalcitonin and its component peptides in systemic inflammation: immunochemical characterization. J Investig Med 1997, 45:552-560.

13. Christ-Crain M, Jaccard-Stolz D, Bingisser R, Gencay MM, Huber PR, Tamm $M$, Muller B: Effect of procalcitonin-guided treatment on antibiotic use and outcome in lower respiratory tract infections: cluster-randomised, single-blinded intervention trial. Lancet 2004, 363:600-607.

14. Christ-Crain M, Muller B: Procalcitonin in bacterial infections - hype, hope, more or less? Swiss Med Wkly 2005, 135:451-460.

15. Marc E, Menager C, Moulin F, Stos B, Chalumeau M, Guerin S, Lebon P, Brunet F, Raymond J, Gendrel D: Procalcitonin and viral meningitis: reduction of unnecessary antibiotics by measurement during an outbreak. Arch Pediatr 2002, 9:358-364.

16. de Kruif MD, Lemaire LC, Giebelen IA, Struck J, Morgenthaler NG, Papassotiriou J, Elliott PJ, van der Poll T: The influence of corticosteroids on the release of novel biomarkers in human endotoxemia. Intensive Care Med 2008, 34:518-522.

17. Salluh Jl, Povoa P, Soares M, Castro-Faria-Neto HC, Bozza FA, Bozza PT: The role of corticosteroids in severe community-acquired pneumonia: a systematic review. Crit Care 2008, 12:R76.

18. Monneret G, Doche C, Durand DV, Lepape A, Bienvenu J: Procalcitonin as a specific marker of bacterial infection in adults. Clin Chem Lab Med 1998, 36:67-68.

19. Oczenski W, Fitzgerald RD, Schwarz S: Procalcitonin: a new parameter for the diagnosis of bacterial infection in the peri-operative period. Eur J Anaesthesiol 1998, 15:202-209.

20. Reinhart K, Karzai W: Re: Procalcitonin: a new parameter for the diagnosis of bacterial infection in the perioperative period. Oczenski et al., Eur J Anaesthesiol 1998; 15: 129-132. Eur J Anaesthesiol 1998, 15:618-619.

21. de Bont ES, Vellenga E, Swaanenburg J, Kamps W: Procalcitonin: a diagnostic marker of bacterial infection in neutropenic cancer patients with fever? Infection 2000, 28:398-400.

22. Gendrel D, Bohuon C: Procalcitonin as a marker of bacterial infection. Pediatr Infect Dis J 2000, 19:679-687; quiz 688.

23. Tang BM, Eslick GD, Craig JC, McLean AS: Accuracy of procalcitonin for sepsis diagnosis in critically ill patients: systematic review and meta-analysis. Lancet Infect Dis 2007, 7:210-217.

24. Reinhart K, Brunkhorst FM: Meta-analysis of procalcitonin for sepsis detection. Lancet Infect Dis 2007, 7:500-502; author reply 502-503.

25. Povoa P, Coelho L, Almeida E, Fernandes A, Mealha R, Moreira P, Sabino H: C-reactive protein as a marker of infection in critically ill patients. Clin Microbiol Infect 2005, 11:101-108.

26. Povoa P, Coelho L, Almeida E, Fernandes A, Mealha R, Moreira P, Sabino $\mathrm{H}$ : C-reactive protein as a marker of ventilator-associated pneumonia resolution: a pilot study. Eur Respir J 2005, 25:804-812

27. Kofoed K, Andersen O, Kronborg G, Tvede M, Petersen J, Eugen-Olsen J, Larsen K: Use of plasma C-reactive protein, procalcitonin, neutrophils, macrophage migration inhibitory factor, soluble urokinase-type plasminogen activator receptor, and soluble triggering receptor expressed on myeloid cells-1 in combination to diagnose infections: 
a prospective study. Crit Care 2007, 11:R38.

28. Opal SM: The host response to endotoxin, antilipopolysaccharide strategies, and the management of severe sepsis. Int J Med Microbiol 2007 297:365-377.

29. Opal SM, Scannon PJ, Vincent JL, White M, Carroll SF, Palardy JE, Parejo NA, Pribble JP, Lemke JH: Relationship between plasma levels of lipopolysaccharide (LPS) and LPS-binding protein in patients with severe sepsis and septic shock. J Infect Dis 1999, 180:1584-1589.

30. Dinarello CA: Interleukin 1 and interleukin 18 as mediators of inflammation and the aging process. Am J Clin Nutr 2006, 83:447S-455S.

31. Groeneveld AB, Tacx AN, Bossink AW, van Mierlo GJ, Hack CE: Circulating inflammatory mediators predict shock and mortality in febrile patients with microbial infection. Clin Immunol 2003, 106:106-115.

32. Haase M, Bellomo R, Baldwin I, Haase-Fielitz A, Fealy N, Davenport P, Morgera S, Goehl H, Storr M, Boyce N, Neumayer HH: Hemodialysis membrane with a high-molecular-weight cutoff and cytokine levels in sepsis complicated by acute renal failure: a phase 1 randomized trial. Am J Kidney Dis 2007, 50:296-304.

33. Kellum JA, Kong L, Fink MP, Weissfeld LA, Yealy DM, Pinsky MR, Fine J, Krichevsky A, Delude RL, Angus DC: Understanding the inflammatory cytokine response in pneumonia and sepsis: results of the Genetic and Inflammatory Markers of Sepsis (GenIMS) study. Arch Intern Med 2007, 167:1655-1663.

34. Yende S, D'Angelo G, Kellum JA, Weissfeld L, Fine J, Welch RD, Kong L, Carter M, Angus DC: Inflammatory markers at hospital discharge predict subsequent mortality after pneumonia and sepsis. Am J Respir Crit Care Med 2008, 177:1242-1247.

35. Ho KM, Lee KY, Dobb GJ, Webb SA: C-reactive protein concentration as a predictor of in-hospital mortality after ICU discharge: a prospective cohort study. Intensive Care Med 2008, 34:481-487.

36. Gibot S, Cravoisy A: Soluble form of the triggering receptor expressed on myeloid cells-1 as a marker of microbial infection. Clin Med Res 2004, 2:181-187.

37. Muller B, Gencay MM, Gibot S, Stolz D, Hunziker L, Tamm M, Christ-Crain M: Circulating levels of soluble triggering receptor expressed on myeloid cells (sTREM)-1 in community-acquired pneumonia. Crit Care Med 2007, 35:990-991.

38. Sunden-Cullberg J, Norrby-Teglund A, Treutiger CJ: The role of high mobility group box-1 protein in severe sepsis. Curr Opin Infect Dis 2006, 19:231-236.

39. Yende S, Tuomanen El, Wunderink R, Kanaya A, Newman AB, Harris T, de Rekeneire N, Kritchevsky SB: Preinfection systemic inflammatory markers and risk of hospitalization due to pneumonia. Am J Respir Crit Care Med 2005, 172:1440-1446.

40. Morris A, Wei K, Afshar K, Huang L: Epidemiology and clinical significance of pneumocystis colonization. J Infect Dis 2008, 197:10-17

41. Louie RF, Tang Z, Albertson TE, Cohen S, Tran NK, Kost GJ: Multiplex polymerase chain reaction detection enhancement of bacteremia and fungemia. Crit Care Med 2008, 36:1487-1492.

42. Ruimy R, Dos-Santos M, Raskine L, Bert F, Masson R, Elbaz S, Bonnal C, Lucet JC, Lefort A, Fantin B, Wolff M, Hornstein M, Andremont A: Accuracy and potential usefulness of triplex real-time PCR for improving antibiotic treatment of patients with blood cultures showing clustered grampositive cocci on direct smears. J Clin Microbiol 2008, 46:2045-2051.

43. Available from: http://www.cdc.gov/nchs/data/nvsr/nvsr56/nvsr56_10.pdf

44. Ng PC, Zhao Q, Levy S, Strausberg RL, Venter JC: Individual genomes instead of race for personalized medicine. Clin Pharmacol Ther 2008, 84:306-309.

45. Fine MJ, Auble TE, Yealy DM, Hanusa BH, Weissfeld LA, Singer DE, Coley CM, Marrie TJ, Kapoor WN: A prediction rule to identify low-risk patients with community-acquired pneumonia. N Engl J Med 1997, 336:243-250.

46. Lim WS, van der Eerden MM, Laing R, Boersma WG, Karalus N, Town Gl, Lewis SA, Macfarlane JT: Defining community acquired pneumonia severity on presentation to hospital: an international derivation and validation study. Thorax 2003, 58:377-382.

47. Charles PG, Wolfe R, Whitby M, Fine MJ, Fuller AJ, Stirling R, Wright AA, Ramirez JA, Christiansen KJ, Waterer GW, Pierce RJ, Armstrong JG, Korman TM, Holmes P, Obrosky DS, Peyrani P, Johnson B, Hooy M, Grayson ML: SMART-COP: a tool for predicting the need for intensive respiratory or vasopressor support in community-acquired pneumonia. Clin Infect Dis 2008, 47:375-384.

48. Mandell LA, Wunderink RG, Anzueto A, Bartlett JG, Campbell GD, Dean NC, Dowell SF, File TM, Jr, Musher DM, Niederman MS, Torres A, Whitney
CG: Infectious Diseases Society of America/American Thoracic Society consensus guidelines on the management of community-acquired pneumonia in adults. Clin Infect Dis 2007, 44(Suppl 2):S27-S72.

49. Muller B, Morgenthaler N, Stolz D, Schuetz P, Muller C, Bingisser R, Bergmann A, Tamm M, Christ-Crain M: Circulating levels of copeptin, a novel biomarker, in lower respiratory tract infections. Eur J Clin Invest 2007, 37:145-152.

50. Christ-Crain M, Breidthardt T, Stolz D, Zobrist K, Bingisser R, Miedinger D, Leuppi J, Tamm M, Mueller B, Mueller C: Use of B-type natriuretic peptide in the risk stratification of community-acquired pneumonia. J Intern Med 2008, 264:166-176

51. Muller B, Suess E, Schuetz P, Muller C, Bingisser R, Bergmann A, Stolz D, Tamm M, Morgenthaler NG, Christ-Crain M: Circulating levels of pro-atrial natriuretic peptide in lower respiratory tract infections. J Intern Med 2006, 260:568-576.

52. Jensen JU, Heslet $L$, Jensen $T H$, Espersen $K$, Steffensen P, Tvede M: Procalcitonin increase in early identification of critically ill patients at high risk of mortality. Crit Care Med 2006, 34:2596-2602.

53. Menendez R, Cavalcanti M, Reyes S, Mensa J, Martinez R, Marcos MA, Filella $X$, Niederman M, Torres A: Markers of treatment failure in hospitalised community acquired pneumonia. Thorax 2008, 63:447-452.

54. Harbarth S, Holeckova K, Froidevaux C, Pittet D, Ricou B, Grau GE, Vadas L, Pugin J: Diagnostic value of procalcitonin, interleukin-6, and interleukin-8 in critically ill patients admitted with suspected sepsis. Am J Respir Crit Care Med 2001, 164:396-402.

55. Luyt CE, Guerin V, Combes A, Trouillet JL, Ayed SB, Bernard M, Gibert C, Chastre J: Procalcitonin kinetics as a prognostic marker of ventilatorassociated pneumonia. Am J Respir Crit Care Med 2005, 171:48-53.

56. Christ-Crain M, Muller B: Procalcitonin and pneumonia: is it a useful marker? Curr Infect Dis Rep 2007, 9:233-240

57. Katan M, Muller B, Christ-Crain M: Copeptin: a new and promising diagnostic and prognostic marker. Crit Care 2008, 12:117.

58. Christ-Crain M, Morgenthaler NG, Stolz D, Muller C, Bingisser R, Harbarth S, Tamm M, Struck J, Bergmann A, Muller B: Pro-adrenomedullin to predict severity and outcome in community-acquired pneumonia [ISRCTN04176397]. Crit Care 2006, 10:R96.

59. Schouten M, Wiersinga WJ, Levi M, van der Poll T: Inflammation, endothelium, and coagulation in sepsis. J Leukoc Bio/ 2008, 83:536-545.

60. Querol-Ribelles JM, Tenias JM, Grau E, Querol-Borras JM, Climent JL, Gomez E, Martinez I: Plasma D-dimer levels correlate with outcomes in patients with community-acquired pneumonia. Chest 2004, 126:1087-1092

61. Bakhtiari K, Meijers JC, de Jonge E, Levi M: Prospective validation of the International Society of Thrombosis and Haemostasis scoring system for disseminated intravascular coagulation. Crit Care Med 2004, 32:2416-2421.

62. Gando S, Iba T, Eguchi Y, Ohtomo Y, Okamoto K, Koseki K, Mayumi T, Murata A, Ikeda T, Ishikura H, Ueyama M, Ogura H, Kushimoto S, Saitoh D, Endo S, Shimazaki S: A multicenter, prospective validation of disseminated intravascular coagulation diagnostic criteria for critically ill patients: comparing current criteria. Crit Care Med 2006, 34:625-631.

63. Dhainaut JF, Yan SB, Joyce DE, Pettila V, Basson B, Brandt JT, Sundin DP, Levi M: Treatment effects of drotrecogin alfa (activated) in patients with severe sepsis with or without overt disseminated intravascular coagulation. J Thromb Haemost 2004, 2:1924-1933.

64. Yende S, Angus DC, Ding J, Newman AB, Kellum JA, Li R, Ferrell RE, Zmuda J, Kritchevsky SB, Harris TB, Garcia M, Yaffe K, Wunderink RG: 4G/5G plasminogen activator inhibitor-1 polymorphisms and haplotypes are associated with pneumonia. Am J Respir Crit Care Med 2007, 176:1129-1137.

65. Chopin N, Floccard B, Sobas F, Illinger J, Boselli E, Benatir F, Levrat A, Guillaume C, Crozon J, Negrier C, Allaouchiche B: Activated partial thromboplastin time waveform analysis: a new tool to detect infection? Crit Care Med 2006, 34:1654-1660

66. Zakariah AN Cozzi SM, Van Nuffelen M Clausi CM, Pradier O, Vincent $\mathrm{J}$ : Combination of biphasic transmittance waveform with blood procalcitonin levels for diagnosis of sepsis in acutely ill patients. Crit Care Med 2008, 36:1507-1512.

67. Laterre PF: Beyond antibiotics in severe community-acquired pneumonia: the role and rationale for tissue factor pathway inhibition. Crit Care 2008 12(Suppl 6):S4.

68. Macfarlane JT, Colville A, Guion A, Macfarlane RM, Rose DH: Prospective study of aetiology and outcome of adult lower-respiratory-tract infections in the community. Lancet 1993, 341:511-514. 
69. Evans AT, Husain S, Durairaj L, Sadowski LS, Charles-Damte M, Wang Y: Azithromycin for acute bronchitis: a randomised, double-blind, controlled trial. Lancet 2002, 359:1648-1654.

70. Christ-Crain M, Stolz D, Bingisser R, Muller C, Miedinger D, Huber PR, Zimmerli W, Harbarth S, Tamm M, Muller B: Procalcitonin guidance of antibiotic therapy in community-acquired pneumonia: a randomized trial. Am J Respir Crit Care Med 2006, 174:84-93.

71. Briel M, Schuetz P, Mueller B, Young J, Schild U, Nusbaumer C, Periat P, Bucher $\mathrm{HC}$, Christ-Crain M: Procalcitonin-guided antibiotic use vs a standard approach for acute respiratory tract infections in primary care. Arch Internal Med 2008, 168:2000-2007; discussion 2007-2008.

72. Cals JW, Butler CC, Hopstaken RM, Hood K, Dinant GJ: Effect of point of care testing for $C$ reactive protein and training in communication skills on antibiotic use in lower respiratory tract infections: cluster randomised trial. Br Med J 2009, 338(Clin Res Ed):b1374.

73. Johnson SB, Lissauer M, Bochicchio GV, Moore R, Cross AS, Scalea TM: Gene expression profiles differentiate between sterile SIRS and early sepsis. Ann Surg 2007, 245:611-621.

74. Yu SL, Chen HW, Yang PC, Peck K, Tsai MH, Chen JJ, Lin FY: Differential gene expression in gram-negative and gram-positive sepsis. Am J Respir Crit Care Med 2004, 169:1135-1143.

75. Tang BM, McLean AS, Dawes IW, Huang SJ, Cowley MJ, Lin RC: Geneexpression profiling of gram-positive and gram-negative sepsis in critically ill patients. Crit Care Med 2008, 36:1125-1128.

76. Wattanathum A, Manocha S, Groshaus H, Russell JA, Walley KR: Interleukin-10 haplotype associated with increased mortality in critically ill patients with sepsis from pneumonia but not in patients with extrapulmonary sepsis. Chest 2005, 128:1690-1698.

77. von Bernuth H, Picard C, Jin Z, Pankla R, Xiao H, Ku CL, Chrabieh M, Mustapha IB, Ghandil P, Camcioglu Y, Vasconcelos J, Sirvent N, Guedes M, Vitor AB, Herrero-Mata MJ, Arostegui Jl, Rodrigo C, Alsina L, Ruiz-Ortiz E, Juan M, Fortuny C, Yague J, Anton J, Pascal M, Chang HH, Janniere L, Rose Y, Garty BZ, Chapel $\mathrm{H}$, Issekutz A, et al:: Pyogenic bacterial infections in humans with MyD88 deficiency. Science 2008, 321:691-696.

78. Ku CL, von Bernuth H, Picard C, Zhang SY, Chang HH, Yang K, Chrabieh M, Issekutz AC, Cunningham CK, Gallin J, Holland SM, Roifman C, Ehl S, Smart J, Tang M, Barrat FJ, Levy O, McDonald D, Day-Good NK, Miller R, Takada H, Hara T, Al-Hajjar S, Al-Ghonaium A, Speert D, Sanlaville D, Li X, Geissmann F, Vivier E, Marodi L, et al:: Selective predisposition to bacterial infections in IRAK4-deficient children: IRAK-4-dependent TLRs are otherwise redundant in protective immunity. J Exp Med 2007, 204:2407-2422.
79. Khor CC, Chapman SJ, Vannberg FO, Dunne A, Murphy C, Ling EY, Frodsham AJ, Walley AJ, Kyrieleis O, Khan A, Aucan C, Segal S, Moore CE, Knox K, Campbell SJ, Lienhardt C, Scott A, Aaby P, Sow OY, Grignani RT, Sillah J, Sirugo G, Peshu N, Williams TN, Maitland K, Davies RJ, Kwiatkowski DP, Day NP, Yala D, Crook DW, et al:: A Mal functional variant is associated with protection against invasive pneumococcal disease, bacteremia, malaria and tuberculosis. Nat Genet 2007, 39:523-528.

80. Walport MJ: Complement. First of two parts. NEngl J Med 2001, 344:1058-1066.

81. Roy S, Knox K, Segal S, Griffiths D, Moore CE, Welsh KI, Smarason A, Day NP, McPheat WL, Crook DW, Hill AV: MBL genotype and risk of invasive pneumococcal disease: a case-control study. Lancet 2002, 359:1569-1573.

82. Kerlin BA, Yan SB, Isermann BH, Brandt JT, Sood R, Basson BR, Joyce DE, Weiler H, Dhainaut JF: Survival advantage associated with heterozygous factor $\mathrm{V}$ Leiden mutation in patients with severe sepsis and in mouse endotoxemia. Blood 2003, 102:3085-3092.

83. Opal S: The link between coagulation and innate immunity in severe sepsis. Scand J Infect Dis 2003, 35:535-544.

84. Tamaki K, Kogata Y, Sugiyama D, Nakazawa T, Hatachi S, Kageyama G, Nishimura K, Morinobu A, Kumagai S: Diagnostic accuracy of serum procalcitonin concentrations for detecting systemic bacterial infection in patients with systemic autoimmune diseases. J Rheumato/ 2008, 35:114-119.

85. Dahaba AA, Rehak PH, List WF: Procalcitonin and C-reactive protein plasma concentrations in nonseptic uremic patients undergoing hemodialysis. Intensive Care Med 2003, 29:579-583.

86. Amour J, Birenbaum A, Langeron O, Le Manach Y, Bertrand M, Coriat P, Riou $B$, Bernard M, Hausfater P: Influence of renal dysfunction on the accuracy of procalcitonin for the diagnosis of postoperative infection after vascular surgery. Crit Care Med 2008, 36:1147-1154.

87. Zethelius B, Berglund L, Sundstrom J, Ingelsson E, Basu S, Larsson A, Venge P, Arnlov J: Use of multiple biomarkers to improve the prediction of death from cardiovascular causes. N Engl J Med 2008, 358:2107-2116.

doi: $10.1186 /$ cc 8155

Cite this article as: Christ-Crain M, Opal SM: The role of biomarkers in the diagnosis and management of community-acquired pneumonia. Critical Care 2010, 12:203 